\title{
理科教育におけるハニカムモアレの利用
}

\author{
村田 滋○, 森田辰郎, 宮崎 眞 (京都工芸繊維大学)
}

\section{Use of artistic honeycomb moiré in science education}

\author{
Shigeru MURATA, Tatsuro MORITA and Makoto MIYAZAKI
}

\begin{abstract}
This paper reports on honeycomb color moiré and its generating method. The honeycomb color moiré is generated by overlapping a pattern of RGB color honeycomb with that of monochrome honeycomb, and it consists of a lot of isolated, large-scaled and different colored clouds of tiny hexagons in honeycomb pattern. The size of each cloud of hexagons is dependent on the size of an elemental hexagon and the crossing angle between the axes on the color and monochrome honeycomb patterns. It is also shown that the color honeycomb moiré can be applied to hidden images or characters.
\end{abstract}

Keywords: Moiré, Honeycomb Pattern, Color Pattern, Science Education, Viewer

\section{1. 活動の背景}

近年全国各地で小中学生を対象とした理科・科学の啓 発活動が盛んに催されるようになった. 京都においても 年に 1 回, 文化の日前後に「青少年のための科学の祭典 京都大会」が開催され, 教育関係者等が各ブースで様々 なテーマを提供することで, 青少年の理科・科学に対す る興味をかき立てようと努力している．著者らは前報 1$)$ において, このような小中学生を対象とした理科教育お よび理科啓発活動において, カラーモアレ縞を利用して 波の基本現象を楽しく経験させる試みについて述べた.

本稿では，ストライプを基本パターンとする通常のモ アレではなく, カラーハニカムパターンを用いてモアレ 縞と同様のスケールの大きなパターンを生じさせる方法 について述べ，その利用例について報告する.

\section{2. カラーハニカムモアレ}

類似した 2 つの縞模様を重ねると, そこに全く異なる 一般に波長の長い縞模様が現れる.これがモアレまたモ アレ縞と呼ばれるもので, 古くから良く知られてきた現 象である. ここでは元の縞模様がハニカムパターンであ る場合を考える. 図 1 はそのパターンを拡大表示したも のであり, (a)は RGB パターン, (b)はそのうち 2 色を黒

(B), 他を白 (W), (c)は(b)の逆のパターンを示してい る. (b), (c)の白色部を透明であるとすると, このまま(a) に(b)を重ねると, 赤色の小六角形のみが透け, 全体とし て赤色に見える. しかし，(a)に(c)を重ねると, 緑色部と 青色部が透けるため, 遠目には全体が水色のように見え

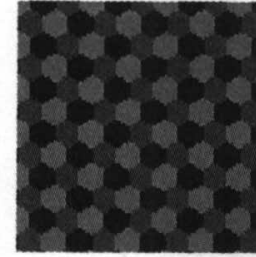

(a) RGB

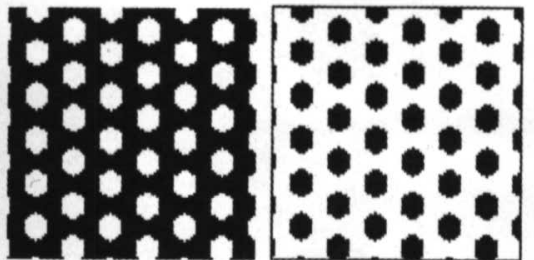

(b) BBW (c) BWW
Fig.1 Elemental honeycomb patterns.

る.この 2 つのハニカムパターンを重ねる角度を変える と, その交差角度に応じて大きな六角形形状の色パター ンが発生する.これを本稿ではハニカムモアレと呼ぶ.

図 2 にハニカムモアレが発生する概念と, そのパター ンサイズと交差角度との関係を図示する. 左下端の赤色 の小六角形の位置を回転中心として, 白黒ハニカムパ夕 ーンを反時計方向に回転させたとしよう，また，回転角 は大きくなく, 中心から水平方向に十分大きな距離を取 った位置で考えると，右下の赤色の小六角形に重なって いた白黒八ニカムの白色(透明)小六角形が，その上の青 色小六角形へと移り, 青色が見えるようになる.ここで, 小六角形の一辺を $\Delta \mathrm{x}$, 白色(透明)小六角形の垂直方向変 位量を $\Delta \mathrm{y}$, 小六角形の外接円半径を $\mathrm{r}$ とすると, 幾何学 的な関係式は

$$
\Delta x=r,
$$

$$
\Delta y=L \tan \varphi
$$


となる．その色の変化が起こる角度 $\varphi$ と回転中心からの 距離 L の関係は次のように評価できる.

$$
\begin{gathered}
L=n(\Delta x+2 r)=3 n r, \\
\tan \varphi=\frac{\Delta y}{L}=\frac{r \cos (\pi / 6)}{3 n r}=\frac{\sqrt{3} r / 2}{3 n r}=\frac{\sqrt{3}}{6 n}
\end{gathered}
$$

ただし, 図 2 では説明の簡単のため, 中心位置から $2 つ$ 目の同色小六角形を示しているが，式では中心から $\mathrm{n}$ 個 隣の同色小六角形位置で示している.これより, ハニカ ムモアレパターンの大きさは

$$
2 L=6 n r=\frac{\sqrt{3} r}{\tan \varphi}
$$

となる.この色パターンは RGB 3 色の繰り返しとなるが, この繰り返しは水平方向だけではなく, 小六角形の右上 方, 左上方のいずれの方向でも同様に生じるため, ある 色の八ニカムモアレは大きな六角形状に生じることにな る.

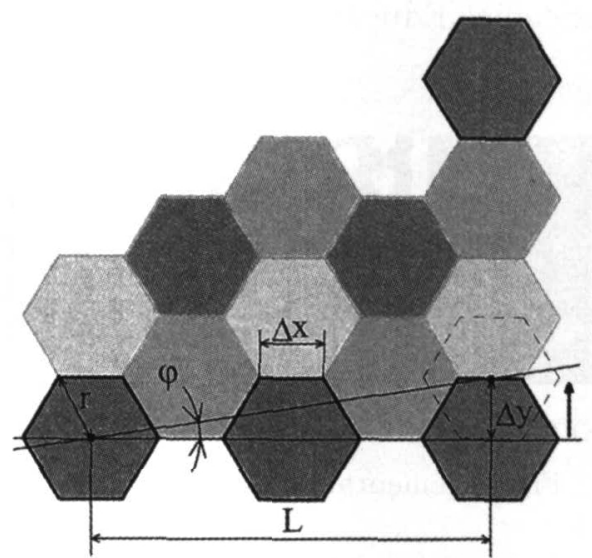

Fig.2 Basic concept of honeycomb moiré generation.

\section{3. ハニカムモアレ形成と利用}

図3に科学の祭典で参加者に製作させたハニカムモ アレピューアの作り方を示す. (1)厚紙に印刷した RGB ハニカムパターンに白黒八ニカムの OHP シートを重ね, (2)中心のパンチ穴位置でかしめ金具で緅じる. (3)OHP

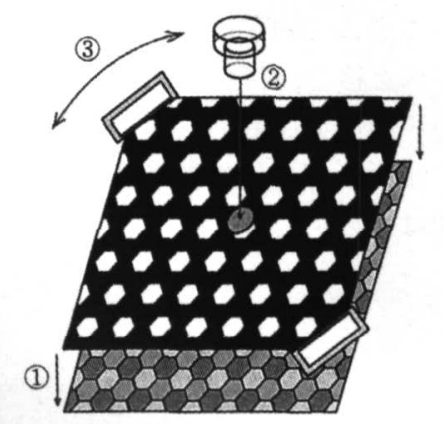

Fig.3 How to make a honeycomb moiré viewer.

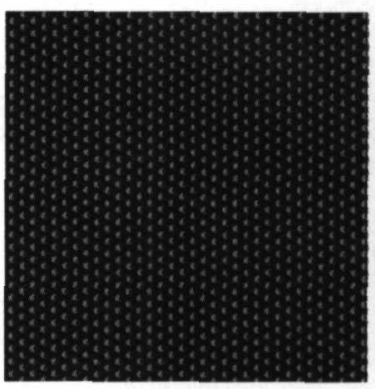

(a) $0 \mathrm{deg}$

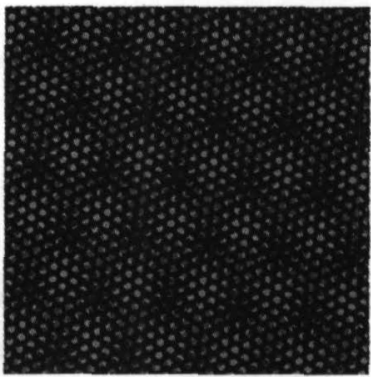

(c) $10 \mathrm{deg}(\mathrm{BBW})$

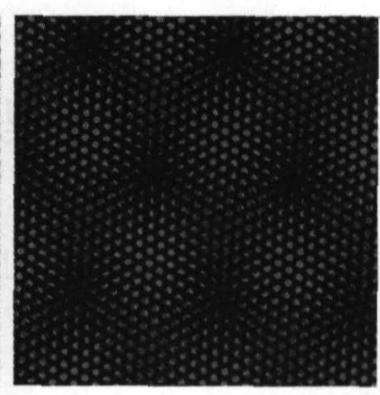

(b) $5 \operatorname{deg}(\mathrm{BBW})$

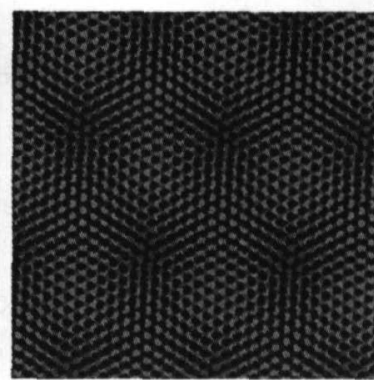

(d) 5 deg (BWW)
Fig. 4 Correlation between rotating angle and generated honeycomb moiré pattern.

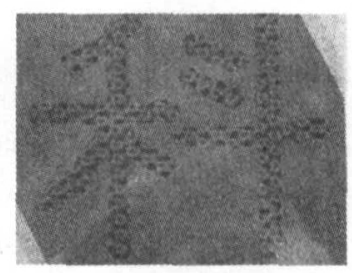

(a)Appeared

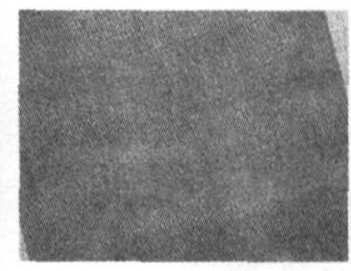

(b)Hidden
Fig.5 An example of hidden character.

シートは角に付けたインデックスを持ち回転させる. 図 4 に発生するハニカムモアレを示す，重ねる交差角度を 大きくするとパターンが細かくなり, また, 透明部面積 比の異なるシート(BWW)を重ねると上述のように色が 変化することがわかる. 交差角度によりハニカムモアレ の細かさが変化するので, この性質を利用すると隐し 絵・隠し文字が楽しめる.八ニカムモアレパターンの大 きさが無限大となる角度設定を背景部と対象像部でず らすだけでよい。図 5 は, 下のカラーハニカムパターン に「科」の字を隠した例である.ハニカムモアレパター ンの大きさは $60 \mathrm{deg}$ 毎に無限大となるので, その角度を 文字部と背景部で $30 \mathrm{deg}$ だけ変化させている． $15 \mathrm{deg}$ または45degではどちらも同程度の細かさの八ニカムモ アレパターンになり, 見分けがつかなくなる.

\section{参考文献}

1) 村田, 宮崎, 森田, 理科教育におけるカラーモアレ縞の利 用, 可視化情報, Vol. 25, Suppl. No. 2 (2005), pp. 355-358.

2) 第 11 回青少年のための科学の祭典京都大会 2006 ガイド プック, (2006). 